\title{
Cost of Capital, Firm Size and Financial Distress
}

\author{
Mark Waita Gichaiya Stephen Muchina Stephen Macharia \\ School of Business, Karatina University, P.O. Box 1957 - 10101, Karatina, Kenya
}

\begin{abstract}
Financial distress (FD) is a global muddle that adversely affects firms and economies. Kenya documents substantive evidence of FD across economic sectors. This indicates a missing link between financial surveillance and business management. Past research concentrates on FD modeling and capital structure effects on performance. This study explored the influence of cost of capital on FD and the moderation effect of firm size. The study was anchored on Modigliani and Miller's second proposition and Trade-off theory. Retrospective longitudinal research design was adopted targeting all non-financial firms listed in Nairobi Securities Exchange (NSE). Hierarchical panel regression analysis explored the multi-dimensional financial data collected from audited financial statements, daily stock prices and market indices from year 2006 to 2015. Findings show cost of capital to relate significantly and negatively with FD. Cost of equity (Ke) rises with cost of debt (Kd). Interaction term cost of capital*firm size has no effect on FD. Kd and Ke significantly influence FD positively and negatively respectively. Interaction $\mathrm{Kd} *$ firm size has a positive insignificant influence on FD while interaction $\mathrm{Ke} *$ firm size has a negative significant effect on FD. The study recommends diligent capital budgeting to ensure firms only invest in feasible ventures surpassing the cost of capital.
\end{abstract}

Keywords: Cost of Capital, Firm Size, Financial Distress.

DOI: $10.7176 /$ RJFA/10-18-05

Publication date:September $30^{\text {th }} 2019$

\section{Introduction}

Financial distress (FD) is a condition leading to possible bankruptcy and collapse due to a company's persistent inability to meet financial obligations. Firms suffering from this condition are identified with high fixed costs, illiquid assets and volatile operating income (Palinko \& Svoob, 2016; Sporta, 2018). Financial statements manifest FD when there is continuous negative working capital or overdue non-current liabilities. Financially distressed firms have also been associated with excessive borrowing to finance unsustainable projects (Carmassi \& Patti, 2015; Edesiri, 2014; Kazemian, Shauri, Sanusi \& Shuhidan, 2017).

FD is a concept dating 40 years back to 1970 s and 80 s where companies in several states suffered from financial crisis owing to excessive borrowing, high cost of short-term debt, overwhelming foreign debt and high default rates (Anderson, 2013; Rashid, 2014). Financial and economic crisis have also prompted financial distress among firms. A savings and loan crisis in 1980s distressed many deposit taking and development financing firms (Anderson, 2013). The Asian crisis that began in 1995 left many trading companies and banks insolvent and distressed (Panahi, 2016). Most recently the 2008/07 global financial crisis caused most emerging economies globally to suffer adverse effects such as; withdrawal of foreign aid, declined international trade, fiscal deficits and distorted financial systems that translated to distressing several firms (Bartmann, 2017; Dullien, 2010).

Listed firms in Kenya have also fallen victim to FD in recent years. Nine publicly trading non-financial firms renown to have experienced severe financial hitches in Kenya include; Uchumi Supermarkets Ltd., Kenya Airways Ltd, Mumias Sugar Company, Marshalls East Africa Ltd., Home Afrika Ltd., A. Baumann \& Co., CMC Holdings, Express Kenya Ltd. and Eveready E.A. These companies have experienced persistent losses, operational inefficiency, take-over bids, delisting, receivership and liquidation (NSE, 2017). Unlisted firms that have also experienced FD include; Nakumatt Holdings, Dubai bank, Chase bank, Imperial banks, Kenatco Transport Ltd., Kisumu Cotton Mills, Pan African Vegetable Products, and E.A. Coast Fisheries (CBK, 2016; Cytonn Investments, 2018; ICDC, 2015).

Appendix I shows a graphical trend of FD, debt leverage and firm size of the 9 NSE listed non-financial firms with eminent cases of FD in between year 2006 and 2015. The graph shows that firm safety reduced (FD increased) with increase in debt leverage and it was more pronounced for firms with larger assets. Therefore, there is an emerging association between FD and financing decisions of a company. Empirical literature has concentrated on the relationship between capital structure and financial performance (Chou, Li \& Yin, 2010; Kirui \& Gor 2018; Mwangi, Makau \& Kosimbei, 2014; Ozkan 1996). Other studies (Cassar \& Holmes, 2003; Faulkender $\&$ Petersen, 2005) examined the effect of firm characteristics on capital structure. Some studies have established the effect of capital structure decisions on FD while controlling for performance related measures (Ikpesu \& Eboiyehi, 2018; Muigai, 2016). Empirical studies also exist on the relationship between cost of capital, capital structure and firm value (Bagga \& Kaur, 2016; Dhankar \& Boora, 1996). These empirical results show that there is a missing link between cost of capital and FD worth investigating. This study therefore aims at establishing the relationship between cost of capital and FD while moderating for the effect of firm size. 


\section{Literature Review}

This study is anchored on the second proposition of Modigliani \& Miller (MM) and trade-off theory. MM capital structure theorems provide the foundation of modern corporate finance theory. MM's second proposition holds that a firm's cost of equity increases with an increment in debt-equity ratio (Modigliani \& Miller, 1958, 1963). Trade-off theory on the other hand postulates that the optimal debt to value ratio in a firm is purely determined by striking a balance in between the costs and benefits of debt financing while assets and investment decisions are held constant (Myers, 1984).

Empirical literature relating to the study was reviewed in establishment of research gaps. Ikpesu and Eboiyehi (2018) studied a sample of 58 manufacturing firms listed in Nigeria Stock Exchange from year 2010 to 2016 and established that capital structure prompts financial distress owing to escalated financial leverage despite borrowing being an opportune norm in the manufacturing sector. On the contrary, Bagga and Kaur (2016) determined that cost of capital negatively relates to financial leverage being a proxy for financial distress in the Indian manufacturing sector. The latter study further proves the existence of a positive relationship between firm value and leverage hence concurring with MM's first proposition with taxes. Comparably, Dhankar (1996) figured out a negative relationship between cost of capital and capital structure using a sample of 26 firms listed in Bombay Stock Exchange from 1981 to 1991. Despite the effect of capital structure decision on firm value varying across firms, it is significant at a multifaceted macro-level that accommodates market factors but insignificant at microlevel where most influential predictors such as firm reputation fails to be measurable (Dhankar, 1996). Elsewhere, Ozkan (1996) analyzed a panel dataset of 195 U.K. firms trading from year 1981 to 1991 and found out that firm characteristics including the asset base, influences FD and capital structure decisions.

Pindado, Rodrigues \& De La Torre (2006) uncovered that FD relates negatively with borrowing based on unbalanced panel data from 402 small Portuguese business ventures from year 1990 - 1997. In addition, small firms in distress zones tend to make irrational financial decisions (Pindado et al., 2006). However, the study fails to account for the financial choices accorded to distressed firms. In a study on publicly trading firms in Kenya, Muigai (2016) upholds that internal equity financing has a negative and significant effect on financial distress concluding that a combination of internal equity and non-current debt financing significantly reduces the probability of distress. Conversely, Kirui and Gor (2018) disputed the pecking order hypothesis on the ground that financially troubled manufacturing firms listed in Kenya from year 1999 to 2016 do not prioritize using internal funds to cater for capital expenditure. The latter study recognizes the divergent effects from cost of debt and cost of equity on the financial status but fails to attach the requisite significance and direction of association they exhibit.

Alifani and Nugroho (2013) proved an inconsistent existence of the second proposition of MM's capital structure theory using a sample of Indonesian firms from year 2003 to 2012 . The study revealed that cost of equity does not necessarily rise with increase in leverage. This holds when cost of debt is greater than cost of equity owing to gradual skewness towards reliance on debt over the years while exhibiting an insufficient EBIT to pay off the finance cost of borrowed funds (Alifani and Nugroho, 2013). On the contrary, Naidu (2013) supports MM's second proposition arguing that return on equity increases when debt levels are high because the leverage induces market reactions from equity shareholders who demand for higher returns as a cover for exposure to more risk. However, Alifani and Nugroho (2013) agrees to the latter supposition only if associated with neutral or risk taking investors that seek for more risk with an expectation of higher returns unlike risk averse investors who shy away from capital structures that accommodate much debt. Damodaran (2016) upholds that the overall cost of capital responds to cost of debt which lenders adequately determine after consideration of default risk while on the other hand investors demand for a higher return on the perception that it should cater for the possible risk of losing their investment due to financial risk from increased leverage. Empirically, it has been proved that debt leverage beyond optimality, induces FD hence denoting a positive significant association between FD and leverage (Carmassi \& Patti, 2015; Kazemian et al., 2017; Khaliq, Altarturi, Thaker, Harun, \& Nurun, 2014; Muigai, 2016; Sporta, 2018). Findings in the latter group of studies concur with the trade-off theory.

Chancharat (2008) determined firm size to have a positive and significant influence on FD using survival analysis techniques on a sample of 1,117 companies trading from year 1989 to 2005 . The study also concluded that large firms exhibit a high probability of being distressed more so if levered. Similarly, Carmassi and Patti (2015) observed large firms to commonly have more debt in their capital structures in comparison to smaller firms hence standing a higher chance of suffering FD. On the contrary, Edesiri (2014) established that firm size represented by total assets, negatively affects FD. The latter study was based on a sample of 120 listed companies in Nigeria from year 1990 - 2013. Ikpesu and Eboiyehi (2018) realized that firm size and FD associates negatively based on a dataset from Nigerian manufacturing firms in between year 2010 - 2016. Likewise, Makeeva and Khugaeva (2018) through a panel logistic regression analysis of 389 innovative firms sampled across the world on the basis of incurring an annual expenditure $>\$ 200$ million, determined that firm size negatively and significantly influences distress. On another note, Rianti and Yadiat (2018) determined that firm size expressed in assets, insignificantly predicts FD among the agricultural firms listed in Indonesia Stock Exchange from year 2012 to 2014. Comparably, Agarwal and Taffler (2008) in a study on FD and momentum anomalies in firms listed in 
London Stock Exchange from year 1979 to 2002, established that firm size in terms of market capitalization does not affect FD.

In reference to moderation from firm size, Ali, Mukulu and Kihoro (2016) explored the interaction effect caused by firm size in the association between functional integration and firm performance proxied by both financial and non-financial facets using a sample of 176 manufacturing firms in Kenya. The study's findings uncovered that the interaction term (firm size*functional integration) had no influence on firm performance thus concluding that firm size as a function of total assets and total sales to be a weak moderator. In contrast, Mutunga and Owino (2017) analyzed the interaction role of firm size in terms of assets and market share in the association between micro-factors and financial performance using a sample of 180 firms trading in Kenya. Micro-factors were operationalized by; production scope, management decisions and business practices. The findings revealed that the interaction term (firm size*micro-factors) has a significant positive effect on firm performance thus concluding that larger firms can embrace leverage to improve their financial performance in contrast to smaller firms that are better off when inclined towards equity financing. Comparatively, Abbasi and Malik (2015) studied firm size in terms of market capitalization as a moderator on the relationship between firm performance and growth using a sample of 50 firms trading in Pakistan. The study results established that the interaction term (firm size*growth) significantly influences firm performance hence concluding that firm size enhances the financial performance of a firm.

The existing literature points out much focus on capital structure optimality that has prompted the development of a number of capital structure theories that still have not resolved the global financial distress chronic muddle. Minimal attention has been accorded to the influence resulting from cost of finance or capital. The existing theories in which this study is premised on also provides a theoretical gap on the basis of contradicting postulations. The tradeoff theory insinuates a positive relationship between financial leverage and financial distress after attaining capital structure optimality. In contrast, MM theorem generally suggests that firm value increases with financial leverage. Empirical literature on firm size provides conflicting significance of its main effect on financial performance and its moderation effect on the relationship between firm characteristics and performance. This study envisages to fill the scholarly gap by evaluating the influence of the overall cost of capital (WACC) as well as the individual effects from costs associated with debt and equity on FD while moderating for firm size in a Kenyan perspective.

\subsection{Research Hypothesis}

$\mathrm{H}_{01}$ : $\quad$ Cost of capital has no significant influence on financial distress in firms quoted at the Nairobi Securities Exchange.

$\mathrm{H}_{02}$ : The interaction of cost of capital and firm size does not significantly influence financial distress in firms quoted at the Nairobi Securities Exchange.

\subsection{Conceptual Model

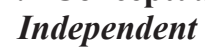

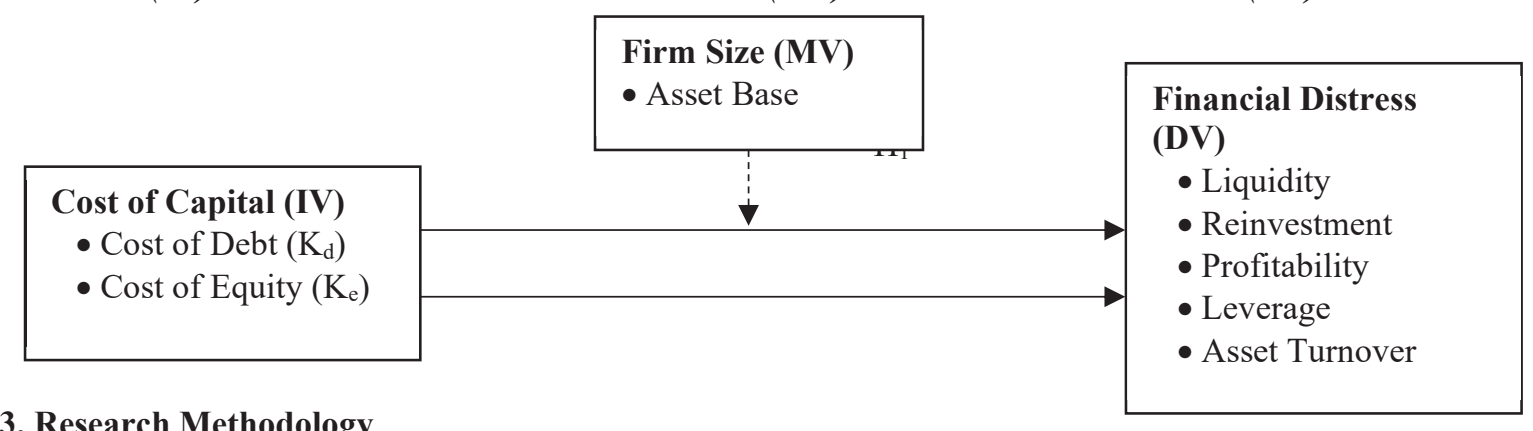

\section{Research Methodology}

\subsection{Research Design and Data}

A longitudinal descriptive research design with a correlational approach formed this study's roadmap in testing the developed hypotheses. The study targeted all non-financial firms listed at NSE from January 2006 to December 2015 as shown in Table 1. Financial firms were excluded because they are strictly regulated in terms of capital reservation and liquidity margins. Secondary longitudinal data was extracted from; published audited financial statements, Central Bank of Kenya published financial market rates, NSE handbooks, NSE stock market indices daily stock prices. 
Table 1: Non-financial Firms Listed in NSE

\begin{tabular}{llc}
\hline$\#$ & Sector Classification & No. of Firms \\
\hline 1. & Agricultural Sector & 8 \\
2. & Automobiles and Accessories & 3 \\
3. & Commercial and Services & 12 \\
4. & Energy and Petroleum & 5 \\
5. & Construction and Allied & 5 \\
6. & Investment (non-financial only) & 3 \\
7. & Manufacturing and Allied & 10 \\
8. & Telecommunication \& Technology & $\underline{1}$ \\
\hline
\end{tabular}

Source: NSE, 2015

\subsection{Measurement of Study Variables}

\subsubsection{Financial Distress (FD)}

This study used Altman's Z-score model to compute indices for FD. Z-score appropriateness and prediction accuracy stands the test of time (Carmassi \& Patti, 2015; Kazemian et al., 2017; Khaliq, et al., 2014). The selected Altman Z-score model builds on ratios that are representative of the inward and outward business environment thus enhancing distress prediction and classification capability. The model takes the form of:
$\mathrm{Z}_{\text {Score }}=0.012 \mathrm{X}_{1}+0.014 \mathrm{X}_{2}+0.033 \mathrm{X}_{3}+0.006 \mathrm{X}_{4}+0.999 \mathrm{X}_{5}$
Subject to the following model constraints
$2.99>\mathrm{Z}>1.8 \quad=$ Grey region firm classification
$\mathrm{Z}<1.8 \quad=$ Distressed firm classification
$\mathrm{Z}>2.99 \quad=$ Non-distressed firm classification

\section{Table 2: Financial Distress Model Variables}

\begin{tabular}{lll}
\hline $\mathbf{X n}$ & Ratio Variable & Objective \\
\hline $\mathbf{X}_{\mathbf{1}}$ & Working Capital to Total Assets [WC/TA] & Measure liquidity level \\
$\mathbf{X}_{\mathbf{2}}$ & Retained Earnings to Total Assets [RE/TA] & Measure reinvestment level \\
$\mathbf{X}_{\mathbf{3}}$ & Earnings Before Interest and Taxes to Total Assets [EBIT/TA] & Measure operating profitability \\
$\mathbf{X}_{\mathbf{4}}$ & Market Value of Equity to Book Value of Total Debt & Measure leverage level \\
$\mathbf{X}_{\mathbf{5}}$ & Sales to Total Assets & Measure assets turnover. \\
\hline
\end{tabular}

\subsubsection{Cost of Capital (CC)}

This is the overall required rate of return for funds provided by shareholders and creditors in financing business operations (Fabozzi \& Drake, 2009). CC at time period ' $t$ ' was computed as the weighted average cost of capital formulated as:

$$
C C=K_{d} * W_{d}+K_{e} * W_{e}
$$

Where

$C C=$ Weighted average cost of capital $(W A C C)$

$K_{d} \quad=$ Cost of Debt

$W_{d} \quad=$ Weight of debt in capital structure

$K_{e} \quad=$ Cost of equity

$W_{e} \quad=\quad$ Weight of equity in capital structure

Additionally, cost of debt $(\mathrm{Kd})$ was derived from the finance cost of long-term borrowed funds after adjusting for; retirement benefits obligations, any deferred compensation and accrued obligations such as deferred tax and deferred revenue. This was determined from:

$$
K_{d}=\frac{F_{c}}{L_{d}}(1-T)
$$

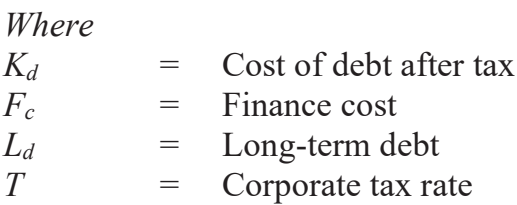

Cost of equity $(\mathrm{Ke})$ on the other hand was determined using capital asset pricing model (CAPM). Rossi (2016) upholds that CAPM's objectivity provides an estimate of cost of equity and it is the basis of supplementing other pricing models. Ke was expressed as the expected return on a stock $\left[E\left(R_{i}\right)\right]$ derived from: 


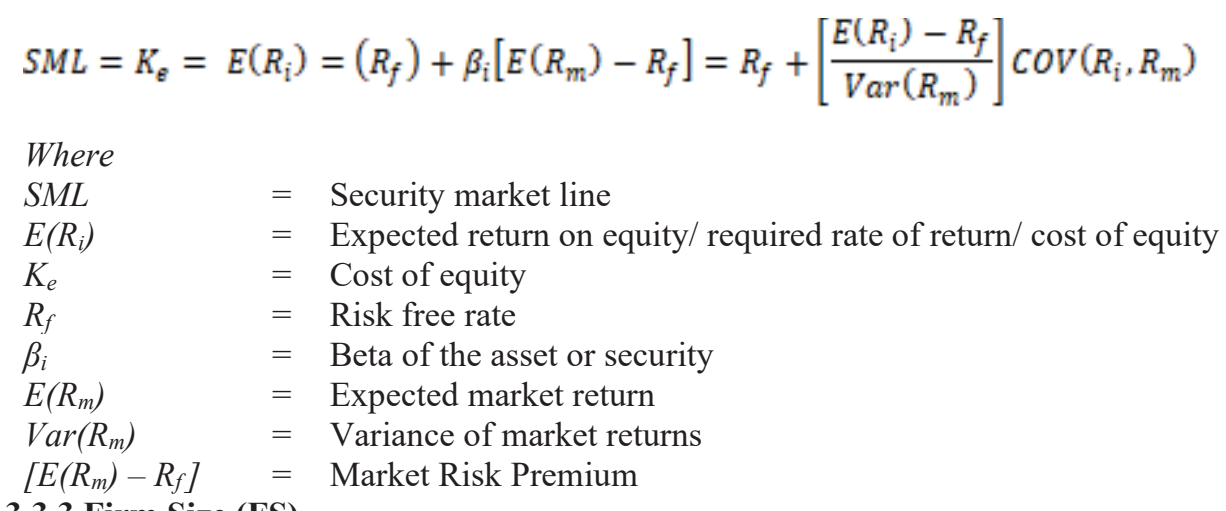

\subsubsection{Firm Size (FS)}

Firm size was measured as a function of total assets further expressed in natural logarithms determined as:

$$
\begin{aligned}
& \text { FS }=\ln (T A)=\ln (N C A+C A)=\log _{e}(N C A+C A) \\
& \text { Given that; } e^{\ln (N C A+C A)}=(N C A+C A) \\
& \text { Where } \\
& F S \quad=\text { Firm size factor } \\
& T A \quad=\text { Total assets [Non-Current Assets (NCA) + Current Assets (CA)] } \\
& \begin{array}{ll}
\text { In } \quad= & \text { Natural Logarithm } \\
e & =\text { Euler's Number }
\end{array}
\end{aligned}
$$

\subsubsection{Data Analysis and Model Specification}

Panel regression analysis was adapted with a rationale of exploring the non-financial longitudinal data that incorporates both the time series and cross sectional effects that vary among the quoted firms in between year 2006 - 2015. Raw financial data was organized with the aid of Microsoft excel spreadsheet and python program. The latter software applications were necessary because of the bulkiness of the data involved. R (version 3.5.3) was applied for panel regression analysis. The regression model is expressed as:

$$
F D_{i t}=\beta_{0}+\sum_{i=1}^{n} \beta_{i} X_{i t}+\mu_{i}
$$

$\begin{array}{ll}\text { Where } & \\ F D_{i t} & =\text { Financial distress index for firm 'i' at time ' } \mathrm{t} \text { ' } \\ i & =\text { Individual firm as a unit of observation (47 non-financial firms) } \\ t & =\text { Time period }(2006,2007, \ldots, 2015) \\ \beta_{o} & =\text { Intercept term } \\ \beta_{i} & =\text { Effect of coefficient variable on the dependent variable } \\ X_{i t} & =\text { Vector of independent variable } \\ \mu_{i} & =\text { Time varying random term/ random error term }\end{array}$

Moderation effect was analyzed hierarchically as listed in hierarchy 1 and hierarchy 2 below.

Hierarchy 1: CC; FS; CC*FS

$$
\begin{array}{ll}
\text { Model 1 } & \mathrm{FD}_{\mathrm{it}}=\beta_{0}+\beta_{1} \mathrm{CC}+\mu_{\mathrm{i}} \ldots \ldots \ldots \ldots \ldots \ldots \ldots \ldots \ldots \ldots \ldots \ldots \ldots \ldots \ldots \\
\text { Model 2 } & \mathrm{FD}_{\mathrm{it}}=\beta_{0}+\beta_{1} \mathrm{CC}+\beta_{2} \mathrm{FS}+\mu_{\mathrm{i}} \quad \ldots \ldots \ldots \ldots \ldots \\
\text { Model 3 } & \mathrm{FD}_{\mathrm{it}}=\beta_{0}+\beta_{1} \mathrm{CC}+\beta_{2} \mathrm{FS}+\beta_{3} \mathrm{CC} * \mathrm{FS}+\mu_{\mathrm{i}}
\end{array}
$$

Hierarchy 2:

$K_{\mathrm{e}} ; K_{d} ; \mathbf{F S} ; K_{\mathrm{e}} * \mathbf{F S} ; K_{d} * \mathbf{F S}$

Model $1 \quad \mathrm{FD}_{\mathrm{it}}=\beta_{0}+\beta_{1} \mathrm{~K}_{\mathrm{d}}+\beta_{2} \mathrm{~K}_{\mathrm{e}}+\mu_{\mathrm{i}}$

Model 2

$$
\mathrm{FD}_{\text {it }}=\beta_{0}+\beta_{1} \mathrm{~K}_{\mathrm{d}}+\beta_{2} \mathrm{~K}_{\mathrm{e}}+\beta_{3} \mathrm{FS}+\mu_{\mathrm{i}}
$$

Model 3

$$
\mathrm{FD}_{\text {it }}=\beta_{0}+\beta_{1} \mathrm{~K}_{\mathrm{d}}+\beta_{2} \mathrm{~K}_{\mathrm{e}}+\beta_{3} \mathrm{FS}+\beta_{4} \mathrm{~K}_{\mathrm{d}} * \mathrm{FS}+\beta_{5} \mathrm{~K}_{\mathrm{e}} * \mathrm{FS}+\mu_{\mathrm{i}}
$$

Where,

$\beta_{\mathrm{o}}=$ Intercept term

$\mu_{\mathrm{i}}=$ Random error term

$\mathrm{FD}_{\mathrm{it}}=$ Financial Distress index for a firm at a given time

$\beta_{1}, \beta_{2} \ldots \beta_{5}=$ Effect of coefficient variable on response variable

CC \&FS $=$ Cost of Capital \& Firm Size

$\mathrm{K}_{\mathrm{e}}=$ Cost of Equity 
$\mathrm{K}_{\mathrm{d}}=$ Cost of Debt

\section{Results and Discussions \\ 4.1 Descriptive Statistics}

The mean Z-score in Table 4 shows that the listed firms are generally safe financially. However, this does not reflect the real picture because on the contrary Table 3 discloses that the percentage of distressed firms rose from $28.9 \%$ in year 2012 to $46.2 \%$ in year 2015 . This therefore signifies that mean as a measure of central tendency is affected by the presence of extreme values in a dataset. Heiman (2011) describes mean as an inaccurate measure when interval or ratio data scales presents a skewed distribution. FD has a standard deviation of 8.638 which also confirms inadequacy of mean due to a high degree of variability. In consensus with Appendix I, Table 3 demonstrates that financial distress has a rising trend across the years the worst being year 2015. Table 4 shows minimal deviance that denotes a modest variation in cost of capital. However, the mean for cost of debt (0.017) is lower than that of cost of equity (0.024) thus implying that debt usage among the listed non-financial firms is a cheaper finance. This can be explained by the fact that debt is commonly pegged on collateral such as fixed assets thus controlling for credit risk unlike equity that is not secured thus shareholders demand for more returns. Furthermore, when a firm is financially constrained, it can opt to cut on dividend payout but still service long term liabilities. Firm size values are descriptively consistent.

Table 3: Classification of Firms

\begin{tabular}{llllllllllll}
\hline Zone\Year & $\mathbf{2 0 0 6}$ & $\mathbf{2 0 0 7}$ & $\mathbf{2 0 0 8}$ & $\mathbf{2 0 0 9}$ & $\mathbf{2 0 1 0}$ & $\mathbf{2 0 1 1}$ & $\mathbf{2 0 1 2}$ & $\mathbf{2 0 1 3}$ & $\mathbf{2 0 1 4}$ & $\mathbf{2 0 1 5}$ & $\mathbf{2 0 0 6 - 1 5}$ \\
\hline $\begin{array}{l}\text { Distress } \\
\begin{array}{l}\text { Frequency } \\
\%\end{array}\end{array}$ & 5 & 5 & 7 & 10 & 8 & 9 & 11 & 12 & 15 & 18 & 100 \\
$\begin{array}{l}\text { Grey } \\
\text { Frequency }\end{array}$ & 14.7 & 14.3 & 20 & 27 & 22.9 & 23.7 & 28.9 & 30 & 37.5 & 46.2 & 27 \\
$\%$ & 14 & 11 & 10 & 8 & 10 & 12 & 8 & 9 & 8 & 7 & 97 \\
$\begin{array}{l}\text { Non-Distress } \\
\text { Frequency }\end{array}$ & 41.2 & 31.4 & 28.6 & 21.6 & 28.6 & 31.6 & 21.1 & 22.5 & 20 & 17.9 & 26.1 \\
$\%$ & 15 & 19 & 18 & 19 & 17 & 17 & 19 & 19 & 17 & 14 & 174 \\
$\%$ & 44.1 & 54.3 & 51.4 & 51.4 & 48.6 & 44.7 & 50 & 47.5 & 42.5 & 35.9 & 46.9 \\
\hline
\end{tabular}

Table 4: Descriptive Summary

\begin{tabular}{llllllll}
\hline Variable & Min & Q1 & Median & Mean & Q3 & Max & SD \\
\hline Z-score & -1.237 & 1.717 & 2.790 & 4.350 & 4.714 & 120.794 & 8.638 \\
CC & -0.135 & 0.021 & 0.039 & 0.041 & 0.055 & 0.367 & 0.345 \\
Kd & 0.000 & 0.002 & 0.012 & 0.017 & 0.023 & 0.172 & 0.020 \\
Ke & -0.153 & 0.005 & 0.022 & 0.024 & 0.040 & 0.342 & 0.343 \\
Firm Size & 17.73 & 21.30 & 22.39 & 22.42 & 23.50 & 26.56 & 1.73 \\
\hline
\end{tabular}

\subsection{Panel Regression Model Diagnostics}

Table 5 presents the results from 4 test statistics used to determine the appropriate panel model for the study on the basis of accepting or rejecting the test associated null hypothesis (at $5 \%$ level of significance). Conclusively, random effects model was deemed most appropriate.

Table 5: Model Diagnostics

\begin{tabular}{|c|c|c|c|c|}
\hline & Test & Statistic & $P$ - value & Test Hypothesis \\
\hline a.) & Lagrange Multiplier - & $x^{2}=221.67$ & $2.2 e-16$ & $\mathrm{H}_{0}:$ No panel effect \\
\hline & Breush Pagan & & & $\mathrm{H}_{1}$ : Panel effect exists \\
\hline b.) & $\begin{array}{l}\text { Lagrange Multiplier - } \\
\text { Honda }\end{array}$ & $x^{2}=14.889$ & $2.2 e-16$ & $\begin{array}{l}\mathrm{H}_{0} \text { : Pooled OLS model is appropriate } \\
\mathrm{H}_{1} \text { : Random effects model is appropriate }\end{array}$ \\
\hline c.) & F-test & $F-=5.5416$ & $2.2 e-16$ & $\begin{array}{l}\mathrm{H}_{0} \text { : Pooled OLS model is appropriate } \\
\mathrm{H}_{1} \text { : Fixed effects model is appropriate }\end{array}$ \\
\hline d.) & $\begin{array}{l}\text { Hausman Specification } \\
\text { Test }\end{array}$ & $x^{2}=0.6149$ & 0.7353 & $\begin{array}{l}\mathrm{H}_{0} \text { : Random effects model is appropriate } \\
\mathrm{H}_{1} \text { : Fixed effects model is appropriate }\end{array}$ \\
\hline
\end{tabular}

\subsection{Linear Regression Diagnostics}

\subsubsection{Outliers}

Mahalanobis distance (cut-off $=5 \%, 3$ variables $[F D, C C, F S]=7.814728)$ and Cook's distance $($ cut-off $=[4 / n$ $k-1]=0.01092896)$ test statistics were used to explore outliers after running an initial regression. Independently, 15 and 12 outliers were identified by Mahalanobis and Cook's distance respectively. However, 5 outliers were common in both tests. All outliers were therefore harmonized to a total of 22. 


\subsubsection{Normality}

Figure 1 visually shows normality of the data distribution using a regression standardized residual histogram and normal quartile-quartile (Q-Q) plot. Normality was further checked against Shapiro-Wilk normality test (W-value $=0.91453 ;$ P-value $=3.693 \mathrm{e}-13$ ). When the data volume is large, Shapiro-Wilk test is objectively interpreted based on how close to 1 the $\mathrm{W}$-value is other than P-value that subjectively leads to type I error owing to an inherent bias that increases chances of rejecting the null hypothesis that data is normally distributed (Das \& Imon,2016; Field, 2009). W-value is closer to 1 hence closer to unity and therefore concluding that the dataset is normally distributed.

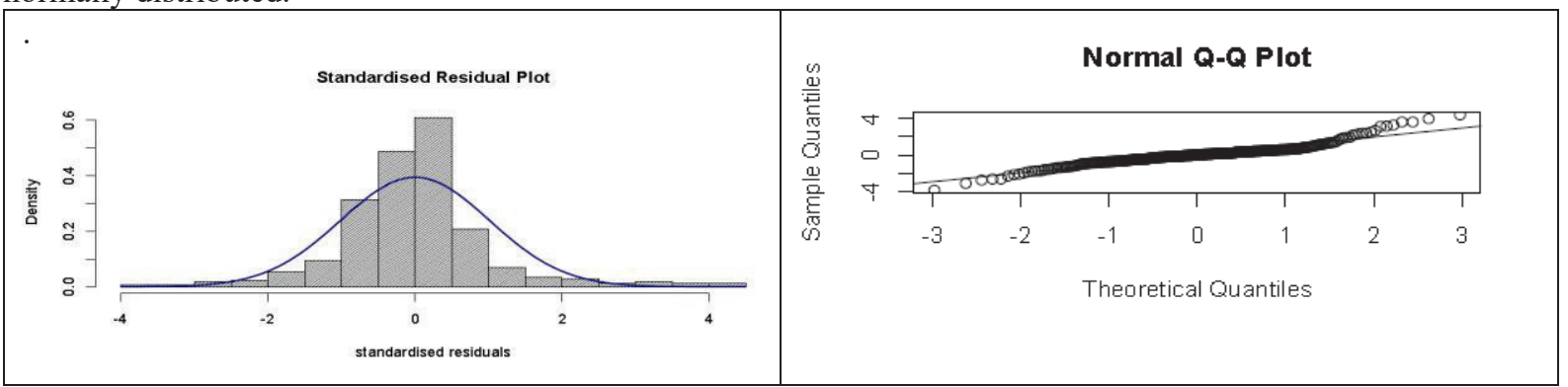

Figure 1: Standardized Residual Histogram and Q-Q plot

\subsubsection{Multicollinearity}

Table 6 shows absence of collinearity between variables because the coefficients of $r$ are far away from being close to perfect correlation $(-1$ or +1$)$ as well as not within the zones for strong positive or strong negative correlation $(0 \geq \mathrm{r}>-0.5 ; 0 \leq \mathrm{r}<+0.5)$. Field (2009) confirms multicollinearity when $r$ almost nears perfect correlation index to an extent of being $>0$.9. In addition, Variance Inflation Factor (VIF) and tolerance statistic results in Table 7 confirms absence of collinearity $(1 \geq \mathrm{VIF} \leq 5$; Tolerance $>0.1)$. VIF ranging between $1-5$ represents insignificant collinearity (Sporta, 2018). Tolerance value is a reciprocal of VIF thus if $<0.1$ collinearity is present (Field, 2009).

Table 6: Correlational Matrix

\begin{tabular}{llll}
\hline & Cost of Capital & Financial Distress & Firm Size \\
\hline Cost of Capital & 1.00000 & 0.18118222 & -0.32543250 \\
Financial Distress & 0.18118222 & 1.00000 & 0.02953245 \\
Firm Size & -0.32543250 & 0.02953245 & 1.00000 \\
\hline
\end{tabular}

Table 7: Collinearity Statistics

\begin{tabular}{lcc}
\hline Variables & \multicolumn{2}{c}{ Collinearity Statistics } \\
\cline { 2 - 3 } & VIF & Tolerance \\
\hline Cost of Capital & 1.1185 & 0.894 \\
Firm Size & 1.1185 & 0.894 \\
\hline
\end{tabular}

\subsubsection{Linearity}

Figure 2 shows a scatter plot that confirms linearity is present. The regression standardized residual points do not fan-out in a curvy pattern and instead they lie along the abline. Schreiber-Gregory (2018) emphasizes that as long data is free from outliers, a scatter plot is ideal to test for linearity.

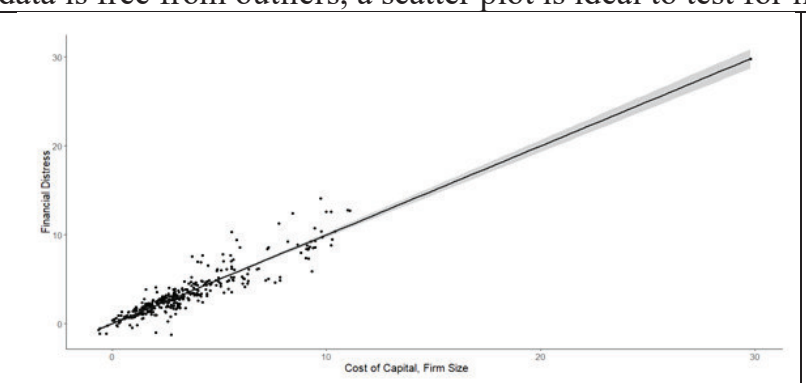

F2.1: Linearity Scatter Plot

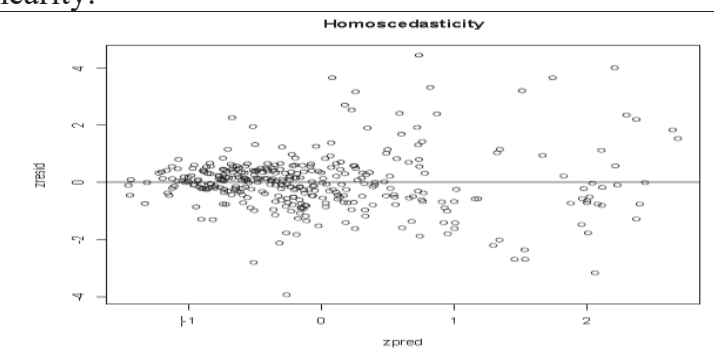

F2.2: Homoscedasticity Scatter Plot

Figure 2: F3.1; F3.2

\subsubsection{Homoscedasticity}

Homoscedasticity scatter plot in Figure 2 shows absence of heteroscedasticity in that the data is randomly scattered around the zero abline indicating constant variance along the predicted values. Plotting standardized residuals against regression standardized predicted values reliably examines homoscedasticity (Osborne \& Water, 2002). 


\subsection{Panel Regression Hierarchical Analysis}

The analysis was premised on random effects model selected in section $\mathbf{4 . 2}$ and after establishing that the dataset conforms to a linear pattern (section 4.3). The analysis was hierarchical as specified in section 3.4. Notably, the higher the financial distress Z-score, the safer a firm is financially as elaborated in section 3.3. The results from hierarchy 1 are shown in Table 8 .

Table 8: Hierarchy 1 Panel Regression Results

\begin{tabular}{|c|c|c|c|c|c|c|c|c|c|}
\hline \multirow[b]{2}{*}{ Predictor } & \multicolumn{3}{|c|}{ Model H1 $\mathrm{H}_{1} 1$} & \multicolumn{3}{|c|}{ Model $\mathrm{H}_{1} \mathrm{M}_{2}$} & \multicolumn{3}{|c|}{ Model $\mathrm{H}_{1} \mathrm{M}_{3}$} \\
\hline & Beta & t-value & $\begin{array}{l}\text { Pr } \\
(>|t|)\end{array}$ & Beta & t-value & $\begin{array}{l}\operatorname{Pr} \\
(>|t|)\end{array}$ & Beta & t-value & $\begin{array}{l}\operatorname{Pr} \\
(>|t|)\end{array}$ \\
\hline (Intercept) & 3.214 & 5.40 & $0.000 * * *$ & 6.012 & 1.128 & 0.260 & 5.701 & 1.032 & 0.303 \\
\hline $\mathrm{CC}$ & 16.291 & 4.495 & $0.000 * * *$ & 16.013 & 4.367 & $0.000 * * *$ & 27.204 & 0.532 & 0.595 \\
\hline FS & & & & -0.132 & -0.528 & 0.598 & -0.119 & -0.462 & 0.645 \\
\hline CC*FS & & & & & & & -0.500 & -0.219 & 0.827 \\
\hline $\mathbf{R}^{2}$ & 0.8661 & & & 0.8662 & & & 0.8662 & & \\
\hline$\Delta \mathbf{R}^{2}$ & 0.8661 & & & 0.0001 & & & 0.0000 & & \\
\hline Adj. $R^{2}$ & 0.8423 & & & 0.8419 & & & 0.8414 & & \\
\hline F-value & 36.44 & & & 35.67 & & & 34.89 & & \\
\hline df & $52^{\mathrm{a}} \& 29$ & & & $53^{a} \& 2$ & & & $54^{a} \& 2$ & & \\
\hline p-value & $2.2 \mathrm{e}-16$ & & & $2.2 \mathrm{e}-16$ & & & $2.2 \mathrm{e}-16$ & & \\
\hline Sig. F & $\mathrm{P}=0.00$ & & & $\mathrm{P}=0.59$ & & & $\mathrm{P}=0.82$ & & \\
\hline Change & & & & & & & & & \\
\hline
\end{tabular}

\section{a. Between columns}

b. Within columns (errors)

Dependent variable: Financial distress

‘***', ‘**’, ‘*’, ‘’ represents $0.1 \%, 1 \%, 5 \%$ \& $10 \%$ significance levels respectively

Model $\mathrm{H}_{1} \mathrm{M}_{1}$ shows cost of capital (CC) as the sole predictor of FD to a significant positive relationship on firm safety $(\beta=16.291 ; t$-value $=4.495 ; P$-value $=0.000<0.05 \alpha)$. This implies that the higher the overall cost of finance, the safer a firm is. Similarly, the cost of capital relates negatively and significantly with FD indicating that a capital structure with both debt and equity portions, results to increased WACC when sourcing for more finance and more so if through borrowing. Reliance on debt exposes equity shareholders to financial risk thus inducing them to demand for more returns. Naidu (2013) establishes that shareholders require a higher return to cater for the risk associated with borrowed funds. Alifani and Nugroho (2013) associates the applicability of this to neutral or risk taking investors only. This is in agreement with Modigliani and Miller's second proposition in that cost of equity increases with rise in debt-equity ratio (Modigliani \& Miller, 1963). This study also concurs with the trade-off theory as well in explaining why cost of capital relates negatively with FD on the premise that before optimality of costs and benefits from borrowing, levered firms enjoy tax shield effects that lowers the financial distress costs irrespective of the increased cost of capital owing to a rise in cost of debt that also prompts an increase in cost of equity. The results are in consensus with a study by Ikpesu and Eboiyehi (2018) that found capital structure decisions to relate negatively with FD. Bagga and Kaur (2016) also figured out that cost of capital is inversely related to leverage that corresponds to FD.

Model $\mathrm{H}_{1} \mathrm{M}_{2}$ introduces firm size as a second predictor of FD. Hierarchically, a moderator is first introduced as a predictor so as to test for its the main effect prior to establishing the interaction effect it causes (Warner, 2013). In comparison to the first model, cost of capital retains a negative significant association with FD (P-value $<0.05$ alpha level) while controlling for firm size. Firm size relates negatively with firm safety although not statistically significant $(\beta=-0.132 ; t$-value $=-0.528 ; P$-value $=0.598>0.05 \alpha)$. The $0.0001 \Delta \mathrm{R}^{2}$ in model $\mathrm{H}_{1} \mathrm{M}_{2}$ at least confirms a main effect from addition of firm size into the model. This further means that firm size on its own has a positive influence on FD. In agreement with the findings, Rianti and Yadiat (2018) determined firm size to insignificantly influence FD. However, the positive effect of firm size on FD could mean that firms strive to expand by financing their asset level through debt beyond optimality between tax shield benefits and bankruptcy related costs hence becoming prone to distress. On the same note, Carmassi and Patti (2015) observed that large firms are commonly financed through debt to a great extent. Chancharat (2008) established that large firms that are financially leveraged, stand a higher chance of becoming financially distressed. Notably, firm expansion comes with increased complexity which if not well managed, exposes a business to probability of financial loss and failure. Contrary to this study's findings, Agarwal and Taffler (2008) ascertained that firm size has no effect on financial distress risk. Elsewhere, some studies support firm size to negatively affect FD (Edesiri, 2014; Ikpesu \& Eboiyehi, 2018; Makeeva \& Khugaeva, 2018).

Model $\mathrm{H}_{1} \mathrm{M}_{3}$ shows results of cost of capital interacting with firm size (CC*FS) as a third predictor. The model accounts for zero change in $\mathrm{R}^{2}\left(\Delta \mathrm{R}^{2}=0.0000\right)$ which is also supported by an insignificant interaction term. 
This implies that there was hardly any interaction effect from firm size and cost of capital on financial distress. Ali et al. (2016) concurs with the interaction results after ascertaining that firm size fails to account for an interaction effect on firm performance with regards to both financial and non-financial aspects. Mutunga and Owino (2017) uncovered inconsistent results that firm size is a positive significant moderator in reference to financial performance. The first and each of the other two models in hierarchy 1 respectively accounts for $86.61 \%$ and $86.62 \%$ variations in financial distress as shown by $\mathrm{R}^{2}$ in Table 8 . The models significantly fit data well compared to an intercept-only model as evidenced by the F-value of 36.44, 35.67 and 34.89 respectively each with a P-value of $2.2 \mathrm{e}-16$ that is $<0.05$ alpha level.

Table 9 shows results from hierarchy 2. Operational variables of CC (cost of debt [Kd] \& cost of equity [Ke]) were regressed against FD indices while testing for interaction effect of firm size (FS).

Table 9: Hierarchy 2 Panel Regression Results

\begin{tabular}{|c|c|c|c|c|c|c|c|c|c|}
\hline \multirow[b]{2}{*}{$\underline{\text { Predictor }}$} & \multicolumn{3}{|c|}{ Model $\mathrm{H}_{2} \mathrm{M}_{1}$} & \multicolumn{3}{|c|}{ Model $\mathrm{H}_{2} \mathrm{M}_{2}$} & \multicolumn{3}{|c|}{ Model $\mathrm{H}_{2} \mathrm{M}_{3}$} \\
\hline & Beta & t-value & $\begin{array}{l}\text { Pr } \\
(>|\mathbf{t}|)\end{array}$ & Beta & t-value & $\begin{array}{l}\text { Pr } \\
(>|\mathbf{t}|)\end{array}$ & Beta & t-value & $\begin{array}{l}\operatorname{Pr} \\
(>|\mathbf{t}|)\end{array}$ \\
\hline (Intercept) & 4.130 & 7.316 & $0.000 * * *$ & 3.483 & 0.705 & 0.481 & 3.913 & 0.787 & 0.432 \\
\hline Kd & -15.905 & -2.839 & $0.005 * *$ & -15.899 & -2.833 & $0.005 * *$ & 112.2 & 1.396 & 0.164 \\
\hline Ke & 21.386 & 6.249 & $0.000 * * *$ & 21.460 & 6.178 & $0.000 * * *$ & -131.6 & -2.678 & $0.008 * *$ \\
\hline FS & & & & 0.031 & 0.132 & 0.895 & 0.003 & 0.014 & 0.989 \\
\hline $\mathrm{Kd}^{*} \mathrm{FS}$ & & & & & & & -5.650 & -1.619 & 0.106 \\
\hline $\mathrm{Ke}^{*} \mathrm{FS}$ & & & & & & & 6.989 & 3.165 & $0.002 * *$ \\
\hline$\overline{\mathbf{R}^{2}}$ & 0.8861 & & & 0.8861 & & & 0.8942 & & \\
\hline$\Delta \mathbf{R}^{2}$ & 0.8861 & & & 0.0000 & & & 0.0081 & & \\
\hline Adj. $\mathbf{R}^{2}$ & 0.8654 & & & 0.8650 & & & 0.8737 & & \\
\hline F-value & 42.87 & & & 41.93 & & & 43.6 & & \\
\hline df & $53^{a} \& 29$ & & & $54^{\mathrm{a}} \& 29$ & & & $56^{a} \& 2$ & & \\
\hline p-value & $2.2 \mathrm{e}-16$ & & & $2.2 \mathrm{e}-16$ & & & $2.2 \mathrm{e}-16$ & & \\
\hline
\end{tabular}

\section{a. Between columns}

\section{b. Within columns (errors)}

Dependent variable: Financial distress

‘***', ‘**', ‘*', ‘’ represents $0.1 \%, 1 \%, 5 \%$ \& $10 \%$ significance levels respectively

Model $\mathrm{H}_{2} \mathrm{M}_{1}$ concurs with model $\mathrm{H}_{1} \mathrm{M}_{1}$ in that $\mathrm{Kd}(\beta=-15.905$; $\mathrm{P}$-value $<0.005)$ and $\mathrm{Ke}(\beta=21.386$; $\mathrm{P}$ value $<0.005$ ) both significantly influence FD. However, Kd has a significant negative association with firm safety this being the equivalent of a significant and positive association with FD while Ke relates positively and significantly with firm safety meaning that the sub-variable has a significant negative relationship with FD. These findings practically explain the role of each cost of capital component with regards to influence on FD. When cost of debt increases, financial leverage is on the rise and therefore a firm becomes more susceptible to financial distress. The results are consistent with past studies showing financial leverage to have a significant and direct association with financial distress (Carmassi \& Patti, 2015; Kazemian et al., 2017; Khaliq et al., 2014; Muigai, 2016; Sporta, 2018). Conversely, the study results show that rise in cost of equity reduces the probability of a firm being financially distressed. This implies that a firm that relies more on equity, is safer financially in contrast to one which accommodates more debt in its capital structure. This is in agreement with Muigai (2016) who found out that equity negatively influences financial distress to a significant extent. Kirui and Gor (2018) ascertained the existence of diverse effects of $\mathrm{Kd}$ and $\mathrm{Ke}$ on financial constraints but failed to account for their significance and directional connotations. The findings further enhance the inference made from model $\mathrm{H}_{1} \mathrm{M}_{1}$ on the argument that a capital structure comprising of debt and equity leads to increase in WACC when extra finance is sourced through borrowing. This is so because despite the cost of debt increasing, cost of equity follows suit as a result of equity shareholders demanding for more returns to cater for financial risk associated with more debt financing. This corresponds to Modigliani and Miller's second postulation that cost of equity increases with financial leverage (Modigliani \& Miller, 1963).

In reference to model $\mathrm{H}_{1} \mathrm{M}_{1}$, model $\mathrm{H}_{2} \mathrm{M}_{2}$ shows that $\mathrm{Kd}$ and $\mathrm{Ke}$ retains their significant positive and significant negative influence on FD respectively while controlling for firm size. On the other hand, firm size has no effect on firm safety $\left(\Delta \mathrm{R}^{2}=0.0000\right)$. Agarwal and Taffler (2008) concurs with this finding. Model $\mathrm{H}_{2} \mathrm{M}_{3}$ tested on interaction effects from $\mathrm{Kd} * \mathrm{FS}$ and $\mathrm{Ke} * \mathrm{FS} . \Delta \mathrm{R}^{2}$ stands at 0.0081 indicating that interaction effect is present. However, interaction term $\mathrm{Kd}^{*} \mathrm{FS}$ has a negative insignificant influence on firm safety $(\beta=-5.650 ; \mathrm{P}>0.05)$ implying that although insignificant, it positively affects FD. This further indicates that high cost of debt increases chances of an entity being financially distressed more so for larger firms. On the other hand, interaction term Ke*FS has a positive significant influence on firm safety $(\beta=6.989 ; \mathrm{P}<0.05)$ implying that it significantly and 
negatively influences FD. This means that increase in cost of equity significantly contributes to lowering the probability of FD among firms that are large in size. The first and second models in hierarchy 2 accounts for $88.61 \%$ while the third accounts for $89.42 \%$ of the variations in FD denoted by $\mathrm{R}^{2}$ in Table 9 . The respective F-values for the 3 models are; $42.87,41.93$ and 43.60 each with a p-value of $2.2 \mathrm{e}-16$ that is $<0.05$ alpha level thus denoting that the models significantly fit the data well compared to an intercept-only model.

\section{Conclusions and Recommendations}

The null hypothesis that cost of capital (CC) has no significant influence on financial distress (FD) was rejected and it was therefore concluded that $\mathrm{CC}$ significantly and negatively associates with FD among the listed nonfinancial firms in Kenya. Both debt and equity components in the capital structure play a role in increasing the weighted average cost of capital. When a firm employ more debt, the finance charge rises and the cost of equity follows suit because debt leverage exposes equity shareholders to more financial risk hence inducing them to demand for more returns in exchange. This more so applies to investors with a risk taking or risk indifferent attitude whereby they seek for more risk with the expectation of higher returns. This is in consensus with Modigliani and Miller's second proposition that specifies cost of equity to increase with rise in debt-equity ratio. The null hypothesis that interaction CC*FS has no significant influence on FD was accepted on the premise that firm size (FS) has no moderating effect on the relationship between CC and FD. However, operational variables of cost of capital relate differently with FD. Cost of debt $(\mathrm{Kd})$ has a positive and significant relation with FD while cost of equity $(\mathrm{Ke})$ relates negatively and significantly with FD. This means each cost has a different role in influencing FD. Kd increases the susceptibility to financial distress in contrast to Ke. The interaction $\mathrm{Kd}^{*} \mathrm{FS}$ has a positive insignificant influence on FD implying that although insignificant, Kd increases chances of larger firms becoming financially distressed. Interaction $\mathrm{Ke} \mathrm{F}^{*} \mathrm{FS}$ has a negative significant effect on FD implying that equity financing significantly contributes to lowering the probability of FD in larger firms. The study recommends that firms should diligently embrace capital budgeting so as to only invest in feasible projects that surpass CC. Investors are sensitive to returns and therefore if returns fail to exceed cost of capital, they re-commit their investment elsewhere to firms with promising returns.

\section{References}

Abbasi, A., \& Malik, Q. A. (2015). Firms' size moderating financial performance in growing firms: An empirical evidence from Pakistan. International Journal of Economics and Financial Issues, 5(2), 334-339.

Agarwal, V., \& Taffler, R. (2008). Does financial distress risk drive the momentum anomaly?. Financial Management, 37(3), 461-484.

Ali, M. J., Mukulu, E., Kihoro, J. M., \& Nzulwa, J. D. (2016). Moderating Effect of Firm Size on the Relationship between Functional Integration and Firm Performance. International Journal of Academic Research in Business and Social Sciences, 6(9), 38-57.

Alifani, G. A., \& Nugroho, A. B. (2013). Proving Modigliani and Miller theories of capital structure: the research on Indonesian cigarette companies. International Journal of Economic Sciences, 2(3), 1-20.

Anderson, S. (2013). A history of the past 40 years in financial crises. International Financing Review, Londres, Inglaterra, 2000, 48-52. Retrieved from http:/www.ifre.com/a-history-of-the-past-40-years-in-financialcrises/21102949.fullarticle

Bagga, R., \& Kaur, J. (2016). Capital Structure, Cost of Capital and Value; A Study of Manufacturing Vis-A-Vis Service Industries in India. PARIPEX-Indian Journal of Research, 5(5).

Bartmann, R. (2017). Causes and effects of 2008 financial crisis. Hochschule Furtwangen. Retrieved from https://opus.hs-

furtwangen.de/frontdoor/deliver/index/docId/1962/file/Bartmann++Causes + and + effects + of $+2008+$ financial + crisis.pdf

Carmassi, C. M., \& Patti, A. (2015). Financial Distress and Bankruptcy: Tools for preserving the Soundness of Financial System. Dissertation. Liberia: Faculty of Economics and Business, Libera University. Retrieved from https://tesi.luiss.it/15689/1/176421.pdf

Cassar, G., \& Holmes, S. (2003). Capital structure and financing of SMEs: Australian evidence. Accounting \& Finance, 43(2), 123-147.

Central Bank of Kenya. (2016). Press Releases. Retrieved from https://www.centralbank.go.ke/press/

Chancharat, N. (2008). An empirical analysis of financially distressed Australian companies: the application of survival analysis. Retrieved from ro.uow.edu.au/cgi/viewcontent.cgi?filename $=0 \&$ article $=1401 \&$ context...

Chou, H. I., Li, H., \& Yin, X. (2010). The effects of financial distress and capital structure on the work effort of outside directors. Journal of Empirical Finance, 17(3), 300-312.

Cytonn Investments. (2018). Restructuring an insolvent business - case study of Nakumatt Holdings \& Cytonn weekly \#12/2018. Retrieved from: https:/cytonn.com/uploads/downloads/restructuring-an-insolventbusiness-case-study-of-nakumatt-holdings-cytonn-weekly-12-2018.pdf 
Damodaran, A. (2016). The Cost of Capital: The Swiss Army Knife of Finance. Retrieved from http://people.stern.nyu.edu/adamodar/pdfiles/papers/costofcapital.pdf

Das, K. R., \& Imon, A. H. M. R. (2016). A brief review of tests for normality. American Journal of Theoretical and Applied Statistics, 5(1), 5-12.

Dhankar, R. S., \& Boora, A. S. (1996). Cost of capital, optimal capital structure, and value of firm: An empirical study of Indian companies. Vikalpa, 21(3), 29-36.

Dullien, S. (2010). The financial and economic crisis of 2008-2009 and developing countries. UN. Retrieved from https://unctad.org/en/Docs/gdsmdp20101_en.pdf

Edesiri, G. O. (2014). Financial leverage behaviour and firm performance: Evidence from publicly quoted companies in Nigeria. Economica, 10 (4), 99 - 106. Retrieved from http://journals.univdanubius.ro/index.php/oeconomica/article/view/2416/2182

Fabozzi, F. J., \& Drake, P. P. (2009). Finance: capital markets, financial management and investment management. Hoboken, N.J: John Wiley \& Sons. Retrieved from https://www.goodreads.com/book/show/8715182-finance

Faulkender, M., \& Petersen, M. A. (2005). Does the source of capital affect capital structure? The Review of Financial Studies, 19(1), 45-79.

Field, A. (2009). Discovering Statistics Using SPSS (3 ${ }^{\text {rd }}$ ed.). London: SAGE Publications Ltd.

Heiman, G. W. (2011). Basic statistics for the behavioral sciences (6th ed.). Wadsworth, Cengage learning.

Ikpesu, F., \& Eboiyehi, O. C. (2018). Capital structure and corporate financial distress of manufacturing firms in Nigeria. Journal of Accounting and Taxation, 10(7), 78-84.

Industrial and Commercial Development Corporation. (2015). ICDC Annual report 2014-2015. Retrieved from http://www.icdc.co.ke/index.php/about-us/publications/financial-reports

Kazemian, S., Shauri, N. A., Sanusi, Z. M., \& Shuhidan, S. M. (2017). Monitoring mechanisms and financial distress of public listed companies in Malaysia. Journal of International Studies, 10(1), 92-109. doi:10.14254/2071-8330.2017/10-1/6

Khaliq, A., Altarturi, B. H., Thaker, H. M., Harun, M. Y., \& Nurun, N. (2014). Identifying Financial distress firms: a case study of Malaysia's government linked companies (GLC). International Journal of Economics, Finance and Management, 3(3), 141-150. Retrieved from http://www.ejournalofbusiness.org

Kirui, B. K., \& Gor, S. O. (2018). Financial Constraints and Firm Capital Structure in Kenya. International Journal of Economics and Finance, 10(1), 177-190.

Makeeva, E. Y., \& Khugaeva, M. O. (2018). Evaluation of financial distress costs of innovative companies. Russian Management Journal, 16 (1), 37-62.

Modigliani, F., \& Miller, M. H. (1958). The cost of capital, corporation finance and the theory of investment. American Economic Review, 48(3), 261-297.

Modigliani, F., \& Miller, M. H. (1963). Corporate income taxes and the cost of capital: a correction. The American Economic Review, 53(3), 433-443.

Muigai, R. G. (2016). Effect of Capital Structure on Financial Distress of Non-Financial Companies Listed in Nairobi Securities Exchange (Doctoral dissertation, COHRED, Finance, JKUAT).

Mutunga, D., \& Owino, E. (2017). Moderating Role of Firm size on the relationship between Micro Factors and Financial Performance of Manufacturing Firms in Kenya. Journal of Finance and Accounting, 1(2), 14-27.

Mwangi, L. W., Makau, M. S., \& Kosimbei, G. (2014). Relationship between capital structure and performance of non-financial companies listed in the Nairobi Securities Exchange, Kenya. Global Journal of Contemporary Research in Accounting, Auditing and Business Ethics, 1(2), 72-90.

Myers, S. C. (1984). The capital structure puzzle. The journal of finance, 39(3), 574-592.

Naidu, W. (2013). The Implications of Capital Structure theory and regulation for South African banking institutions (Doctoral dissertation, University of Pretoria).

Nairobi Securities Exchange. (2015). Listed companies. Retrieved from https://www.nse.co.ke/listedcompanies/list.html

Nairobi Securities Exchange. (2017). Listed companies - company announcements. Retrieved from https://www.nse.co.ke/listed-companies/list.html

Osborne, J., \& Waters, E. (2002). Four assumptions of multiple regression that researchers should always test. Practical assessment, research \& evaluation, 8(2), 1-9.

Ozkan, A. (1996). Costs of financial distress and capital structure of firms (Doctoral dissertation, University of York).

Palinko, E., \& Svoob, A. (2016). Main Causes and Process of Financial Distress. Public Finance Quarterly, 61(4), 516. Retrieved from https:/www.asz.hu/storage/files/files/public-finance-quarterlyarticles/2016/palinko_2016_4_a.pdf

Panahi, O. P. (2016). The Asian Financial Crisis of 1997 to 1998 Revisited: Causes, Recovery and the Path Going Forward. Retrieved from https://www.researchgate.net/publication/299467654

Pindado, J., Rodrigues, L., \& De La Torre, C. (2006). How does financial distress affect small firms' financial 
structure? Small Business Economics, 26(4), 377-391.

Rashid, A. (2014). Firm external financing decisions: explaining the role of risks. Managerial Finance, 40(1), $97-$ 116. doi:10.1108/MF-02-2013-0049

Rianti, I. P., \& Yadiat, W. (2018). How financial distress is influenced by firm size. International Journal of Scientific \& Technology Research, 7, (1), 149-153.

Rossi, M. (2016). The capital asset pricing model: a critical literature review. Global Business and Economics
Review
$18(5)$,
604-617.
Retrieved
from

https://www.researchgate.net/profile/Matteo_Rossi6/publication/307180424_The_capital_asset_pricing_mo del_a_critical_literature_review/links/58ab1a514585150402035426/The-capital-asset-pricing-model-acritical-literature-review.pdf

Schreiber-Gregory, D. N. (2018). Logistic and Linear Regression Assumptions: Violation Recognition and Control. Henry M Jackson Foundation.

Sporta, F. O. (2018). Effect of Financial Distress Factors on Performance of Commercial Banks in Kenya (Doctoral dissertation, JKUAT). Retrieved http://ir.jkuat.ac.ke/bitstream/handle/123456789/4617/Sporta\%2C\%20Fred\%20Ochogo\%20PhD\%20BA\%2 8 finance $\% 29 \% 2 \mathrm{C} \% 202018 . p d f$ ? sequence $=1 \&$ isAllowed $=\mathrm{y}$

Tharkuta, S. G. (2015). Understanding research philosophy. Retrieved from https://www.projectguru.in/publications/research-philosophy/

Warner, R. M. (2013). Moderation: Tests for interaction in multiple regression. Applied Statistics from Bivariate Through Multivariate Techniques, 2, 611-644.

\section{Appendix I: Financial Trend of Distresssed Firms in Kenya}

\section{UCHUMI FINANCIAL TREND}

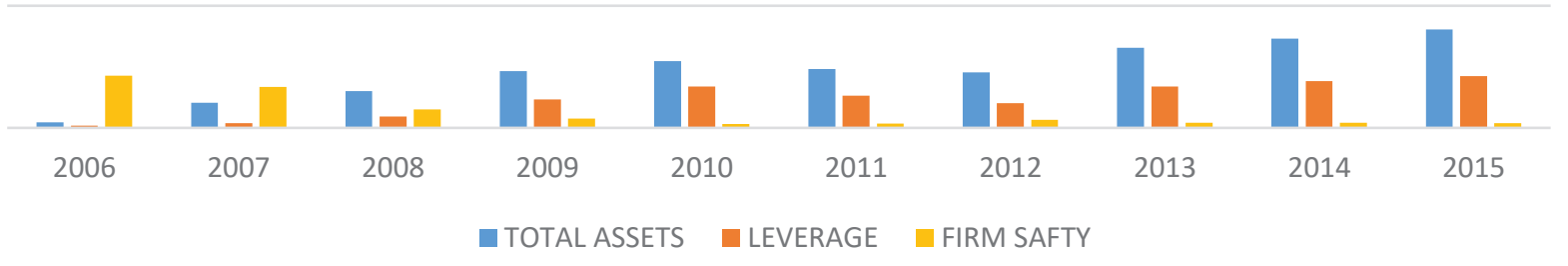

KQ FINANCIAL TREND

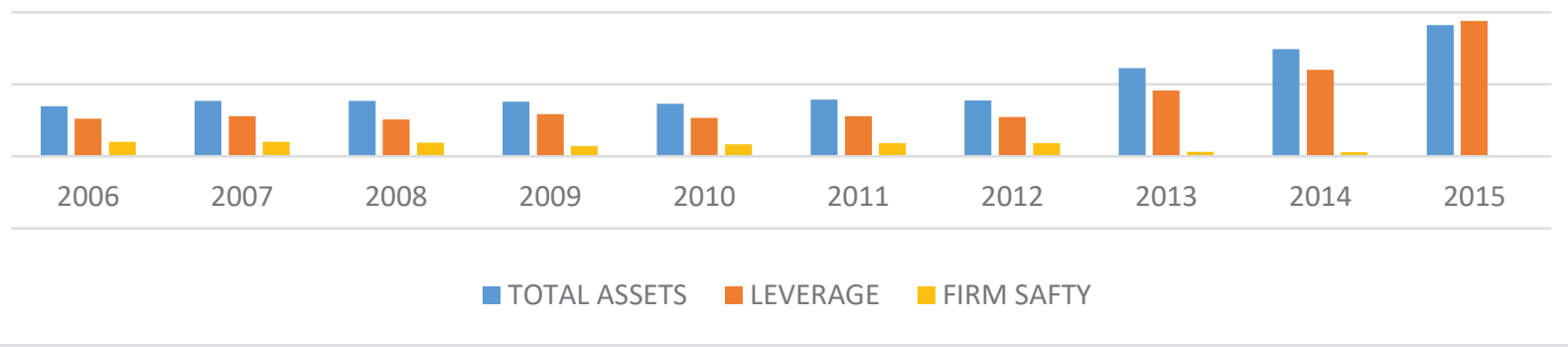

\section{MUMIAS FINANCIAL TREND}

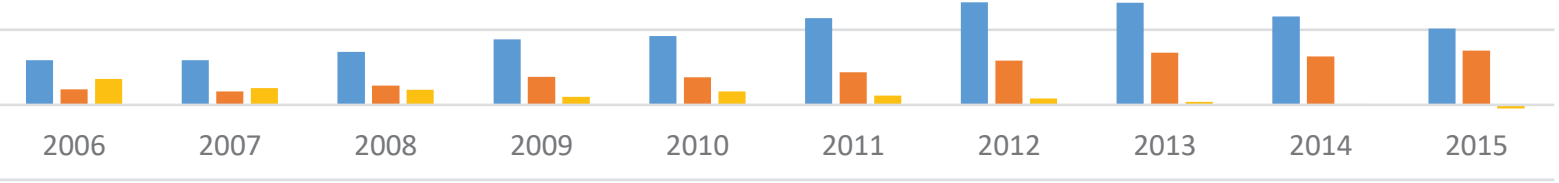




\section{MARSHALLS E.A. FINANCIAL TREND}

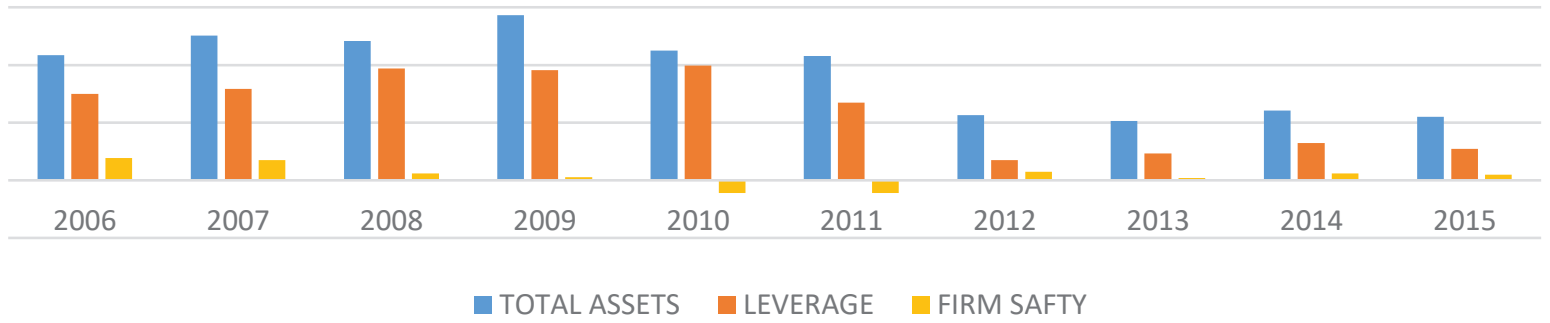

HOME AFRIKA FINANCIAL TREND

A BAUMANN \& Co. FINANCIAL TREND

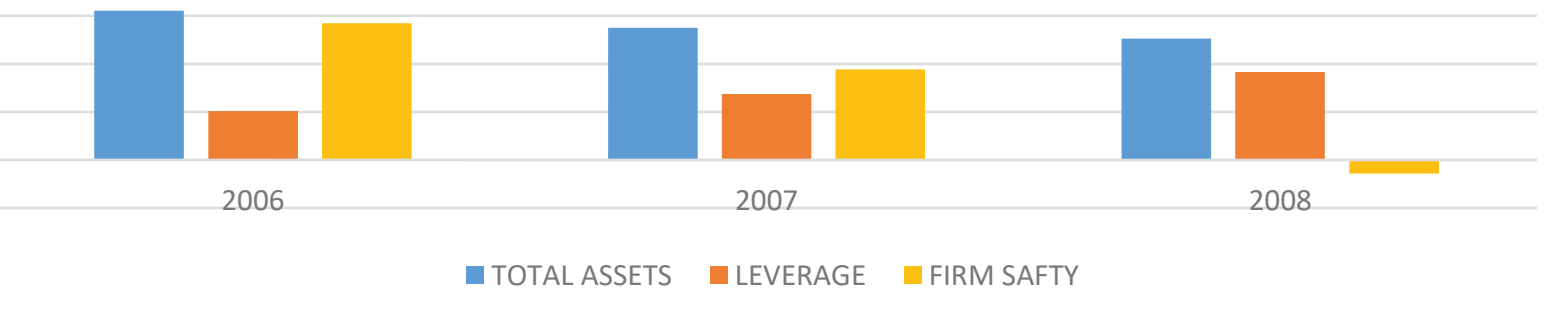

CMC FINANCIAL TREND

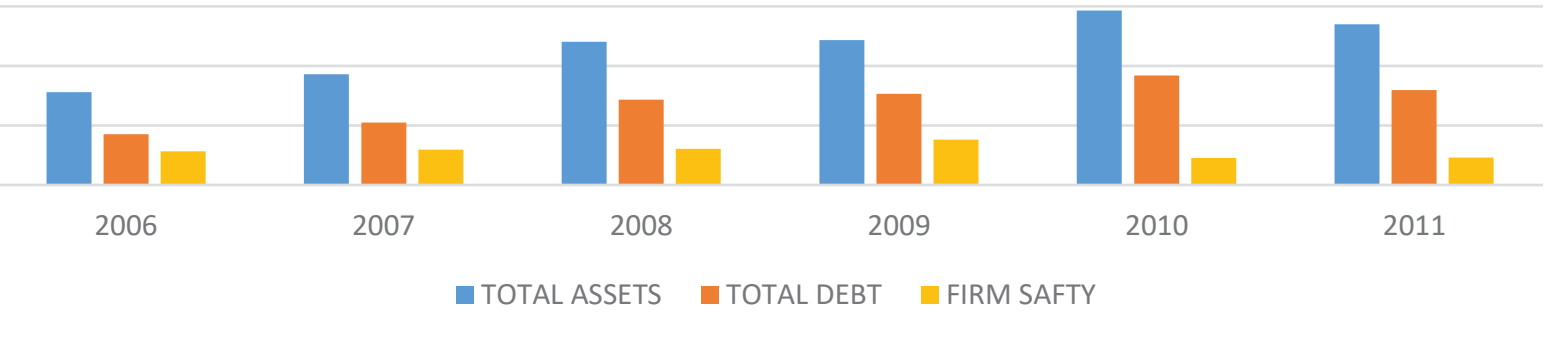




\section{EXPRESS KENYA FINANCIAL TREND}
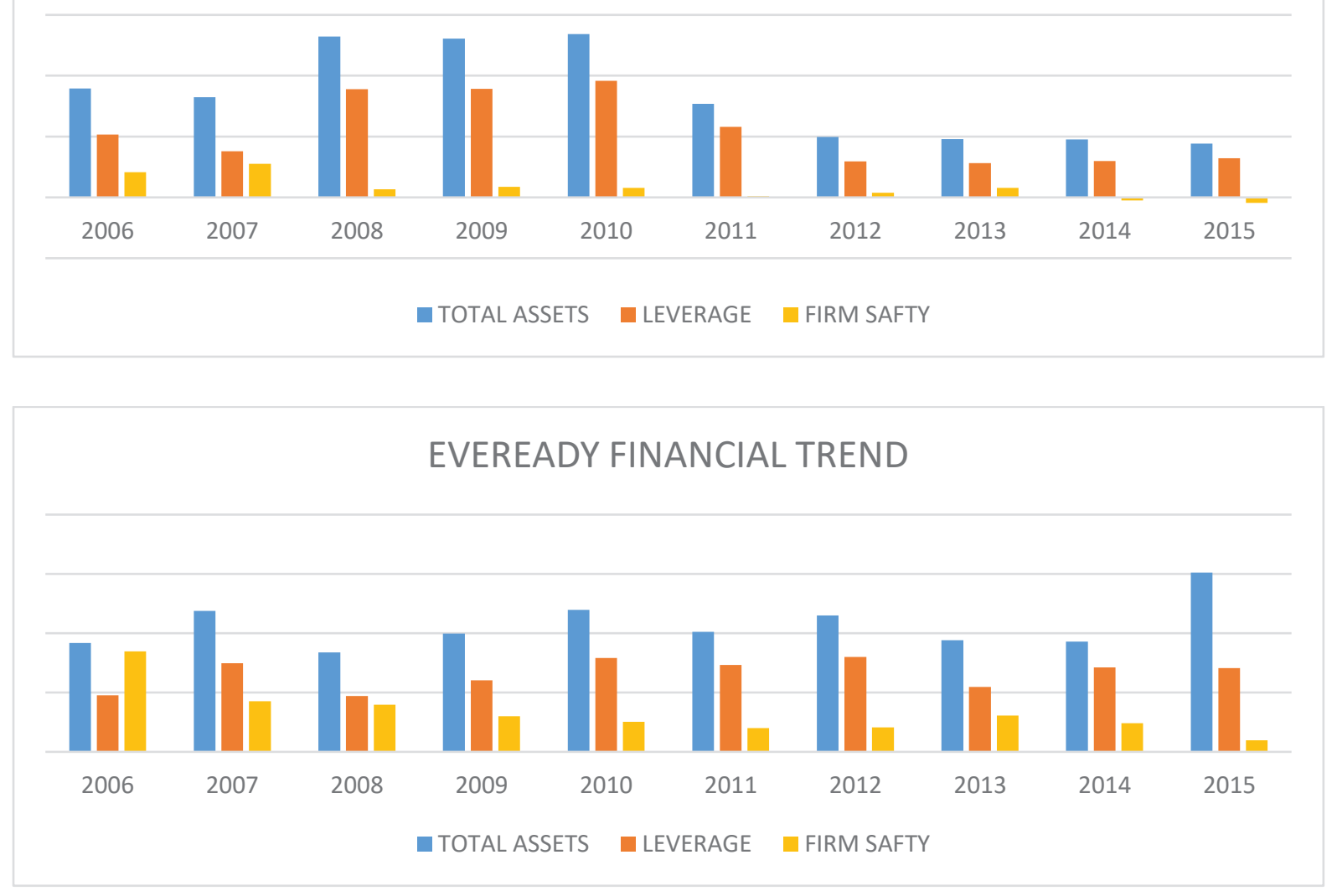

Notes:

- Leverage and total assets related positively in most firms implying that firm size proxied by asset base was financed by debt. However, in the case of A. Baumann \& Co. Ltd., debt leverage rose as firm safety and size shrank.

- Firm safety had a diminishing trend over time. This implies that financial distress rose across the years towards the approach of 2015 .

- Some firms such as Marshalls E.A. and Express Kenya opted to dispose assets to repay debt but that never mitigated financial distress as shown in graphs.

- The financials of some firms did not feature in every year of the study period to either being listed at NSE after year 2006 (Home Afrika Ltd.) or being suspended (A. Baumann \& Co. Ltd. and CMC Holdings).

\section{Sources}

http://www.uchumi supermarket.co.ke; https://www.kenya-airways.com/ke/en/; http://www.marshalls.co.ke; https://www.homeafrika.com; http://www.cmcmotors.com/kenya; http://expresskenya.co.ke;

http://eveready.co.ke; http://www.nse.co.ke; https://www.cma.or.ke 